\title{
Political self-determination of Ukrainian youth
}

\author{
Lebedynska A.*
}

Kremenchuk Mikhailo Ostrogradskyi National University, Kremenchuk, Ukraine

Received: $10.04 .2019 \quad$ Accepted: 26.04 .2019

\begin{abstract}
The article goes about political potential formation and realization problems of the new generation of Ukrainian youth. The specifics of young citizens' formation of political self-determination are emphasized. The specifics of political and social resources of youth as a special socio-demographic group is analyzed. The differentiation of young people value ideas, which determine the degree of their engagement in the political sphere of Ukrainian society, is given. Political self-determination is considered as a process of perception and active manifestation of socio-political experience. The Author deals with the sources of the concept of political identity in western political science. Also the correlation between political identity and political socialization is analyzed from the point of view Ukrainian political scientists. The article analyzes the results of sociological studies of political preferences of young people. The level of their interest in political events is considered as an indicator of the sociopolitical self-determination of Ukrainian youth. Based on authors sociological study data it is given a characteristics of individual components of civic self-determination (civic identity, patriotism, civicengagement ). On the one hand, young people have the necessary potential to influence the political sphere of the state, and on the other hand, they need to be supported by their social activity from state and public institutions. The authors show that young citizens are distinguished by the liability of consciousness, the instability of political orientations and attitudes. Given characteristics of a youth group can contribute to its disorganization and the development of protest behavior. The prospects for the realization of the political potential of young citizens are substantiated. Political education is of primary importance in the development of the political subjectivity of young people in modern conditions. Attention is focused on objective and subjective factors influencing the processes of political socialization and participation of young people in the political process of the country. The individual and psychological, social and psychological factors determines youth political activity indirectly through the system of political behavior motives.

Key words: youth, political process, political potential, political self-determination, political engagement, political selfconsciousness, political activity, involvement into political life, psychological factors of political activity.
\end{abstract}

\section{Політичне самовизначення українського юнацтва}

Лебединська Г. 0.

Кременчуцький національний університет імені Михайла Остроградського, Кременчук, Україна

Анотація. У статті розкриваються проблеми фрормування та реалізації політичного потенціалу нового покоління української молоді. Визначається специфіка становлення політичного самовизначення молодих громадян. Аналізуються особливості політичних і соціальних ресурсів молоді як соціально-демографічної групи. Характеризуються ціннісні уявлення молоді, що обумовлюють ступінь її включення в політичну сферу українського суспільства. Політичне самовизначення розглядається як процес сприйняття і активного прояву соціально-політичного досвіду. У статті проаналізовано результати соціологічних досліджень політичних уподобань молоді. Як показник соціально-політичного самовизначення української молоді розглядається рівень ї̈ інтересу до політичних подій. 3 одного боку, молодь має необхідний потенціал впливу на політичну сферу держави, а з іншого - потребує підтримки своєї соціальної активності з боку державних і громадянських інститутів. Визначено, що молодих громадян відрізняє лабільність свідомості, нестійкість політичних орієнтацій, і поглядів. Такі характеристики молодіжної групи можуть сприяти ї̈ дезорганізації і розвитку протестної поведінки. Обгрунтовано перспективи реалізації політичного потенціалу молодих громадян засобами політичного виховання, яке має першорядне значення в становленні політичної суб'єктності молоді.

\footnotetext{
Corresponding Author: Lebedynska Hanna Oleksandrivna. Phone: +38(096) 385-90-37. E-mail: lebedinskagunna@gmail.com Kremenchuk Mykhailo Ostrohradskyi National University, vul. Pershotravneva, 20, Kremenchuk, Poltava Region, Ukraine, 39600.

Відповідальний автор: Лебединська Ганна Олександрівна. Тел. +38(096) 385-90-37. E-mail: lebedinskagunna@gmail.com Кременчуцький національний університет імені Михайла Остроградського, вул. Першотравнева, 20, м. Кременчук Полтавської обл., Україна, 39600.
} 
Акцентується увага на об'єктивних і суб'єктивних чинниках, що впливають на процеси політичної соціалізації та участь молоді в політичному процесі країни.

Ключові слова: молодь, політичний процес, політичний потенціал, політичне самовизначення, політична участь, політична самосвідомість.

\title{
Политическое самопределение украинской молодежи
}

\author{
Лебединская А. А.
}

Кременчугский национальный университет имени Михаила Остроградского, Кременчуг, Украина

\begin{abstract}
Аннотация. В статье раскрываются проблемы формирования и реализации политического потенциала нового поколения украинской молодежи. Определяется специфика формирования политического самоопределения молодых граждан. Анализируются особенности политических и социальных ресурсов молодежи как социально-демографической группы. Характеризуются ценностные представления молодежи, обусловливающие степень ее включения в политическую сфреру украинского общества. Политическое самоопределение рассматривается как процесс восприятия и активного проявления социальнополитического опыта.

В статье проанализированы результаты социологических исследований политических предпочтений молодежи. В качестве показателя социально-политического самоопределения украинской молодежи рассматривается уровень ее интереса к политическим событиям. С одной стороны, молодежь имеет необходимый потенциал влияния на политическую ссреру государства, а с другой - нуждается в поддержке своей социальной активности со стороны государственных и общественных институтов. Показано, что молодых граждан отличает лабильность сознания, неустойчивость политических ориентаций и взглядов. Данные характеристики молодежной группы могут способствовать ее дезорганизации и развитию протестного поведения. Обоснованы перспективы реализации политического потенциала молодых граждан, где политическое воспитание имеет первостепенное значение в становлении политической субъектности молодежи. Акцентируется внимание на объективных и субъективных факторах, влияющих на процессы политической социализации и участия молодежи в политическом процессе страны.
\end{abstract}

Ключевые слова: молодежь, политический процесс, политический потенциал, политическая самоопределение, политическое участие, политическое самосознание.

\section{Bcmyn}

Вітчизняний та міжнародний досвід свідчить, що демократичні перетворення в державі неможливі без участі громадян. Розбудова громадянського суспільства неможлива без відповідних політичних орієнтацій та індивідуальних позицій щодо політичної системи, в якій живе особистість. Молодь $є$ одним з найважливіших стратегічних ресурсів будь-якого суспільства. Вбираючи в себе цінності і норми, вразливе відповідаючи на соціальні, політичні, економічні зміни саме молодь дає імпульси спрямованості в розвитку суспільства. Участь у політичному житті $є$ безпосереднім показником самовизначення особистості, проявою розуміння людиною свого соціального статусу та можливостей.

Особливо значущим стає формування та розвиток політичності підростаючих поколінь, зокрема юнацтва. Саме на період юності припадає виникнення такого особистісного новоутворення, як самовизначення. Воно характеризується усвідомленням суб'єкта себе як члена суспільства й конкретизується у новій, суспільно значимій позиції. Молодь $є$ найбільш активною, динамічною групою населення, яка досить швидко реагує на всі зрушення та зміни, що відбуваються в суспільстві,

Сьогоднішнє українське суспільство переживає становлення нової соціальної суб'єктивності. Особливістю цього процесу $є$ невизначеність уявлень особистості про спільність інтересів, зумовлена несформованістю громадянського суспільства.

Політична ідентифікація особистості в нестабільному, кризовому суспільстві натрапляє на незвичні зовнішні чинники: мінливість соціальних взаємозв'язків, нез'ясованість функцій основних політичних інститутів, плюралізм культур та ідеологій, протиборство корпоративних (групових) інтересів, яке виливається у війну підконтрольних мас-медіа.

У ситуації порівняно низької структурованості політичного простору, що спостерігається в Україні, перебіг процесу політичного самовизначення утруднюється. Актуально дослідити соціальнопсихологічні чинники, які сприяють активній позиці молоді ї в громадсько-політичному житті. Потреба такого виду самовизначення нерозривно пов'язана з усвідомленням політичної ситуації в суспільстві, формуванням більш менш стійких політичних та ідеологічних уподобань, симпатій, антипатій, уявлень 
про необхідне у сфрері політичних відносин, певною особистісною автономією в прийнятті електоральних рішень і загалом у політичному виборі.

Молоде покоління Україні становить близько третини населення країни. При цьому дана категорія людей - не просто значна частина електорату. Молодь $€$ найбільш активна, і радикальна частина суспільства. У рамках цієї соціальної групи сконцентрована колосальна потенційна енергія.

Метою cmammi $€$ дослідження специфіки становлення політичної позиції громадян юнацького віку.

\section{II Матеріал і методи дослідження}

Сьогодні юнацтво опинилось в умовах нестабільної суспільної свідомості, коли немає затребуваних ідеалів в минулому, але і в теперішньому ще не віднайдені нові орієнтири, які були б адекватні змінам, що відбуваються в країні та світі.

Воднораз, сучасний етап соціального розвитку суспільства «зсунув» у психологічному і «діяльнісному» планах межі всіх вікових етапів у бік більш ранньої зрілості (у тому числі соціальної). На відміну від порівняно недавнього минулого, до осіб молодого віку (21 рік та старше), які «щойно» закінчили ВН3, суспільством застосовується термін «вже дорослі люди». У зв'язку з цим зростає значущість юнацького віку як для успішного формування особистості, так і для продуктивного соціального розвитку суспільства.

Політичне самовизначення молоді - це процес усвідомлення своєї громадянської належності, конструювання своєї суб'єктності і вибору способів соціального участі в перетвореннях країни. Для того щоб особистість стала суб'єктом свого розвитку, вона повинна пройти непростий шлях від елементарних форм поведінки до вищих форм саморегульованої системи. Звісно ж, що тільки особистість, що володіє суб'єктністю здатна до самовизначення, а значить, до реалізації своїх сутнісних сил в умовах нелінійного характеру соціальних змін [1].

Дослідник з питань соціології молоді Ю. В. Березутский говорить про три основні аспекти політичного самовизначення молоді: політична ідентичність, патріотизм і політична участь; всі разом вони складають громадянську позицію [2].

Політична самоідентифікація особистості - це процес солідаризації індивіда з певною політичною спільнотою, змістом та ідеологією соціальної групи, її політичними символами. Сформувавшись під впливом політичної соціалізації, людина бере на себе певну політичну роль з певним набором прав, привілеїв та обов'язків. Метою цього процесу $є$ його адаптація до певної системи, становлення як громадянина [3].

Отже, політична ідентифікація сприяє формуванню політичної свідомості особистості, раціональної орієнтації в політичному житті, самостійного політичного мислення та політичної поведінки. У міру засвоєння індивідом соціокультурних зразків, норм, цінностей, прийняття і засвоєння різних ролей у взаємодіях з іншими людьми його самоідентиффікації змінюються, і більш-менш остаточно його ідентичність складається до кінця юнацького віку.

Особливий інтерес становить дослідження феномена політичної ідентифікації в юнацькому віці, оскільки саме в цей період, на межі шкільного та післяшкільного періодів, відбувається самовизначення особистості, становлення громадянської позиції. В юнацькому віці відбувається динамічне формування моральної свідомості, ціннісних орієнтацій та ідеалів, стійкого світогляду, громадянських якостей особистості.

Вивченню юнацького віку в сучасній психології присвячено багато досліджень. Разом з тим існують великі розбіжності в поглядах на основні імпульси розвитку в юності, часові межі та головні особливості цього періоду. За даними більшості сучасних вітчизняних періодизацій психічного розвитку віковий період, що цікавить нас, від 18 до 22 років, прийнято відносити до юності (Г. С. Абрамова) або пізньої юності (Б. С. Волков).

Кордони юності пов'язують із віком обов'язкової участі в суспільному житті. Юнак повинен взяти на себе відповідальність за пристрій життя, у тому ступені, у якому це можливо в конкретних соціальних умовах. «I 3 цього погляду, юність - це вік участі у виборах в органи державної влади» [4, с. 506]. У даний віковий період індивід характеризується підвищеною емоційною сензитивністю й сугестивністю, у цей період соціальний індивід також виробляє свої ідеали й ціннісні пріоритети. 
Аналізуючи ціннісні орієнтири сучасної української молоді дослідник Савчук О. В. наводить такі цифри щодо співвідношення спрямованості особи: приймають громадську спрямованість - 35\%, особисту - 50\%, керуються мотивом самоствердження - 70\%, прагнуть матеріальних цінностей - 60\%, духовних $-43 \%$ [5].

У політичній психології все ще недостатньо розроблений концепт громадянської ідентичності.

Ситуації в Україні, кольорові революції, близькосхідні конфрлікти дозволяють спостерігати, як руйнуються колишні і створюються нові ідентичності, як легко формуються нові ідеології. Дослідниця соціальної ідентичності Т. В. Шамовська зазначає кризовий стан даного аспекту громадянського самовизначення, яке проявляється, з одного боку, в прихильності молодих людей історично сформованим цінностям соборності і колективізму, а з іншого - цінностям лібералізму і споживацтва [6]. Ці протиріччя підривають можливість формування зрілої громадянської ідентичності молодого покоління.

Патріотизм - невід'ємна ознака цивілізованої людини, саме це почуття єднає людей у націю, батьківщину, стимулює до праці і подвигів в ім'я їх збагачення і розквіту, сповнює почуттям гордості за рідну землю, історію і культуру свого народу.

Цікаві результати соціологічного опитування, проведеного у 2018 з метою з'ясування сутності патріотизму у розумінні сучасної української молоді. Виявлено, що найсильніший вплив на становлення патріотичних почуттів молоді має родина, а також навчальні заклади. Більшість респондентів не схвалює нав'язливого пропагування патріотизму і визнає ефективність тих засобів його розвитку, які дозволяють наочно познайомитися зі здобутками української культури, успіхами українців у різних сферах діяльності. Опитування показало, що 62,2 \% респондентів вважають себе патріотами України, не вважають себе патріотами 16,3 \% респондентів. Цікавим є той факт, що понад $20 \%$ тих, хто вважає себе патріотом, хотіли б виїхати з України [7].

Національна свідомість та самосвідомість особистості є дуже важливою складовою громадянської свідомості та самосвідомості. У зв'язку з цим цікаво процитувати одне з висловлювань польського спеціаліста з проблем етики 3. Шаварського. Він, зокрема, зазначав, що не $є$ хорошим громадянином той, хто не відчуває емоційного зв'язку зі своєю вітчизною, з її історією та традиціями, хто не відчуває своєї відповідальності за її свободу і незалежність, хто не хоче думати про її майбутнє. Бути патріотом означає не тільки бути готовим приносити в разі необхідності жертви, здійснювати героїчні вчинки, але це означає також бути готовим до щоденної, відповідально виконуваної праці, відповідально ставитися до своїх громадських обов'язків [8].

У сучасній Україні спостерігається нормальний процес піднесення самосвідомості української політичної нації з певними рисами етноцентризму.

За даними різноманітних соціологічних спостережень можна стверджувати, що більш відкрите до демократії суспільство спонукає громадян до активної політичної участі.

Проблема політичної участі досліджувалась в працях західних політологів, зокрема американських, таких, як М. Гоел, Р. Кловард, Р. Міллс, Л. Мілбрайт, Ф. Півен тощо. В Україні ця тема привертає все більш уваги. Дослідників чимало, серед них І. Бекешкіна, В Васютинський, А. Горбачик, О. Куценко, О. Чемшит, Н. Ротар та ін.

До найбільш поширеного типу політичної участі відноситься електоральна поведінка. На її спрямованість впливає насамперед ідентифікація конкретного виборця з певною соціальною групою або партією. Психологічна близькість до групи обмежує спектр політичних орієнтації і альтернатив, спрощуючи політичний вибір. Численні дослідження показали, що на думку виборців впливає безліч чинників (стать, вік, конфесійна належність,особливості первинної соціалізації та ін.), але існують деякі загальні тенденції поведінки окремих електоральних груп. Так, молодь певною мірою тяжіє до радикалізму і охоче віддає свої голоси тим, хто обіцяє швидкі зміни. Ї̈̈ виборчі орієнтації розходяться 3 орієнтаціями більшості суспільства, а рівень активності відносно невисокий.

Вперше проблемою теоретичного дослідження електоральної поведінки почали цікавитися у США в 20-ті роки XX століття. Чарльзом Меріамом була створена Чиказька школа досліджень політичної поведінки. Докладну характеристику цього проекту здійснив Г. Алмонд, проаналізувавши не тільки його змістовні особливості, але й методику, зокрема особливості вибіркового методу, який полягав у сполученні випадкової вибірки й квотування за основними демографічними характеристиками. 
Важливим етапом прикладних досліджень електоральної поведінки стала діяльність у США Інституту Дж. Геллапа. У 1960-ті роки свій внесок у розвиток досліджень електоральної поведінки зробили фрранцузькі дослідники Ж. Стецель, М. Брюле, Г. Мішеля, а пізніше - Ф. Бон, Ж. Ранісе, Е. Дюпуар'є, Б. Руе, А. Лансело та ін. [9].

В Україні поведінка виборців активно досліджується через вивчення виборів, політичної участі, пасивності, ефрективності інструментів маніпулювання громадською думкою. Цим проблемам присвячені праці таких українських дослідників: Г. Циганенко, С. Протоцька, М. Головатий, В. Бунь, О. Вишняк [10].

Ключовим складником політичної культури особистості з огляду на ситуацію політичного вибору $є$ політичні орієнтації-установки на самого себе («Я») у контексті політичних відносин. Від усвідомлення свого місця (становища) у структурі політичної системи суспільства, об'єктивної оцінки власних можливостей впливати на прийняття політичних рішень залежить і політична активність особистості.

Ідентичність набувається людиною в ході індивідуального розвитку і є результатом психологічних процесів соціалізації, ідентифрікації, особистісної інтеграції тощо.

\section{III Результати}

Особливості політичного самовизначення юнацтва виступали предметом авторського соціологічного дослідження, проведеного в 2019 р в Кременчуці методом анкетування у віці від 18 до 20 років.

Основна мета емпіричного дослідження - з'ясувати переважні тенденції політичної ідентифікації українського юнацтва. Тобто йшлося про з'ясування того, чи виявляють юні громадяни схильність, прагнення, готовність до політичної ідентифікації, чи, навпаки, демонструють відхід, небажання приєднуватись, ідентифікуватися.

у якості чинників, що обумовлюють спрямованість громадянського самовизначення, розглядалися: 1) сприйняття суспільно-політичного курсу розвитку українського суспільства; 2) рівень задоволеності ситуацією в країні; 3) факти соціального тиску і підтримки щодо необхідності громадянської активності молодої людини; 4) ціннісні орієнтації на самоствердження, самозречення, соціальні зміни і стабільність.

Результати опитування наведені в таблицях 1, 2, 3, 4, 5, 6 у відсотках. Питання ставились у відповідності до складових громадянського самовизначення.

Табл. 1. Сприйняття суспільно-політичного курсу розвитку українського суспільства

\begin{tabular}{|l|c|}
\hline \multicolumn{1}{|c|}{ Змістовне наповнення } & $\%$ опитаних \\
\hline Україна буде демократичною європейською державою & 33,3 \\
\hline Україна буде країною, що йде особливим шляхом розвитку & 26,6 \\
\hline Україна буде слаборозвинутим придатком Заходу & 20 \\
\hline Україна зникне як самостійна держава & 16,6 \\
\hline Мені не цікаво майбутнє цієї країни & 3,3 \\
\hline
\end{tabular}

Табл. 2. Рівень задоволеності ситуацією в країні

\begin{tabular}{|l|c|}
\hline \multicolumn{1}{|c|}{ Змістовне наповнення } & \% опитаних \\
\hline Я не бачу жодного кандидата, за якого було б варто голосувати & 10 \\
\hline Не вірю, що вибори будуть проведені чесно & 26,6 \\
\hline Мені байдужі ці вибори, бо моє життя від них аж ніяк не залежить & 0 \\
\hline Вибори нічого не змінять, бо Президент насправді нічого не вирішує & 10 \\
\hline Мене взагалі не цікавить політика & 6,6 \\
\hline
\end{tabular}

Оцінюючи перспективи майбутнього України, відносна більшість $(33,3 \%)$ юнацтва бачать її високорозвинутою, демократичною, впливовою європейською країною. 26,6\% опитаних вважають, що Україна піде особливим шляхом розвитку. Менші частки респондентів вважають, що Україна назавжди 
стане слаборозвинутим придатком Заходу або зникне як самостійна держава (по 20\% та 16,6\% відповідно). Ці позиції дуже близькі за змістом і разом становлять 36,6\%, а це третина опитаних. Байдуже ставлення до майбутнього власної держави хоч і становить невеликий відсоток (3,3\%), проте свідчить не тільки про аполітичність, а й про відсутність патріотизму у ціннісних орієнтаціях цих представників юнацтва.

Найбільш часто мотивом неучасті у виборах молодь називала сумніви щодо чесних виборів (26,6\%). Інші мотиви називають значно менші частки респондентів.

Табл. 3. Ціннісні орієнтації на самоствердження, самозречення

\begin{tabular}{|l|c|}
\hline \multicolumn{1}{|c|}{ Змістовне наповнення } & \% опитаних \\
\hline $\begin{array}{l}\text { Звичайно, важливими є і свобода, і достаток, при цьому заради особистої } \\
\text { свободи та гарантій дотримання всіх громадянських прав я готовий терпіти } \\
\text { певні матеріальні труднощі }\end{array}$ & 26,6 \\
\hline $\begin{array}{l}\text { Звичайно, важливими є і свобода, і достаток, при цьому в обмін на власний } \\
\text { добробут я готовий поступитися державі часткою своїх прав і } \\
\text { громадянських свобод }\end{array}$ & \\
\hline Важко відповісти & 43,3 \\
\hline
\end{tabular}

В уявній ситуації вибору між свободою і громадянськими правами, з одного боку, і матеріальним добробутом - 3 іншого, відносна більшість (43,3\%) готові поступитися державі часткою своїх прав і громадянських свобод. Натомість, 26,6\% опитаних - навпаки висловили готовність терпіти певні матеріальні труднощі заради особистої свободи та гарантій дотримання всіх громадянських прав. Ще $30 \%$ - не визначилися з вибором. Це свідчить, що для молоді юнацького віку матеріальна незалежність, прагнення мати все тут і зараз домінує над духовними цінностями. А ті що не визначилися із ціннісною спрямованістю складають третину опитаних. Це свідчить про громадянську невизначеність.

Табл. 4. Ціннісні орієнтації на соціальні зміни і стабільність

\begin{tabular}{|l|c|}
\hline \multicolumn{1}{|c|}{ Змістовне наповнення } & $\%$ опитаних \\
\hline Демократія є найбільш бажаним типом державного устрою для України & 66,6 \\
\hline $\begin{array}{l}\text { За певних обставин авторитарний режим може бути кращим, ніж } \\
\text { демократичний }\end{array}$ & 13,3 \\
\hline $\begin{array}{l}\text { Для такої людини, як я, не має значення, демократичний режим у країні чи } \\
\text { ні }\end{array}$ & 6,6 \\
\hline Важко відповісти & 13,3 \\
\hline
\end{tabular}

Відповідаючи на питання про найбільш бажаний тип державного устрою для України, більша половина $(66,6 \%)$ респондентів визначили в такій якості демократію. Натомість 13,3\% - вважають, що за певних обставин кращим може бути авторитарний режим. Для 6,6\% опитаних немає значення, демократичний режим у країні чи ні, а ще 13,3\% - не визначилися з відповіддю. Це може свідчити про формування у більшості громадян усталеного, ціннісного ставлення до демократії.

Табл. 5. Факти громадянської активності молодої людини

\begin{tabular}{|l|c|}
\hline \multicolumn{1}{|c|}{ Змістовне наповнення } & $\%$ опитаних \\
\hline Упевнений що братиму участь & 30 \\
\hline Скоріше за все, братиму участь & 50 \\
\hline Скоріше за все, не братиму участі & 13,3 \\
\hline Упевнений, що не братиму участі & 3,3 \\
\hline Важко сказати напевно, ще не вирішив & 3,3 \\
\hline
\end{tabular}


Щодо такої складової громадянського самовизначення як політична активність на прикладі електоральної участі, то переважна більшість юнацтва висловила бажання за будь яких умов брати участь у виборах. Президентські вибори в Україні традиційно характеризуються високим інтересом виборців та рівнем їх явки. I бажаючих приєднатись до політичного процесу після 2014 року збільшилось в рази. Але між бажанням і діями є певна різниця і до дільниць дійшло менше третини.

Це підтверджують й результати досліджень М. Дмитрієвої [11], показники когнітивного розвитку політичної активності можуть бути досить високими, а поведінкові практично нульовими. Тому реальна політична залученість юнацтва може бути значно нижчою, ніж задекларована в ході нашого дослідження.

Окремо респондентам було запропоновано визначитись із політико-ідеологічним спрямуванням.

На питання «В політиці є «ліві» і «праві». Де за своїми поглядами Ви розташовуєтеся?»

Табл. 6. Політико-ідеологічним спрямування

\begin{tabular}{|l|c|}
\hline \multicolumn{1}{|c|}{ Змістовне наповнення } & $\%$ опитаних \\
\hline Ліві & 3,3 \\
\hline Ліво центристи & 10 \\
\hline Центристи & 43,3 \\
\hline Право центристи & 10 \\
\hline Праві & 3,3 \\
\hline Не відповіли & 30 \\
\hline
\end{tabular}

Жоден з ідейно-політичних напрямів не користується переважаючою підтримкою молоді. Серед кременчуцького юнацтва переважають центристські погляди, але цілком може бути, що цей вибір має ірраціональну природу. Молоді Кременчука бракує фундаментальних знань 3 політики, так як політологія в університеті не викладається. Джерелом інформації є виключно 3Мl або сім'я. Не змогли визначитися щодо самоідентифікації з тим чи іншим ідейно-політичним напрямом третина опитаних.

Політико-ідеологічне самовизначення є процесом, який передбачає вироблення власної ідейнополітичної позиції шляхом співвіднесення системи політичних, загальносуспільних цінностей та ідеалів і системи індивідуальних потреб, прагнень, настановлень у процесі впорядкування особистістю уявлень про доцільний вибір суспільно-політичних моделей розвитку. Потреба такого виду самовизначення нерозривно пов'язана з усвідомленням політичної ситуації в суспільстві, формуванням більш менш стійких політичних та ідеологічних уподобань, симпатій, антипатій, уявлень про необхідне у сфрері політичних відносин, певною особистісною автономією в прийнятті електоральних рішень і загалом у політичному виборі.

\section{IV Обговорення}

Одже, громадянськість - стан свідомості, духовно-моральна цінність, світоглядно-психологічна характеристика людини, обумовлена його державною самоідентифікацією, усвідомленням належності до конкретної країні. Вона є показником ставлення індивідів до існуючого порядку, інститутів держави та влади, виразом міри їхньої законослухняності та критичності, почуття власної гідності в стосунках 3 представниками влади, знання і поваги прав людини, готовності і вміння вимагати їх дотримання, 3 відповідальністю ставитися до своїх обов'язків перед суспільством [12].

Аналіз вітчизняної та російської психологічної літератури показав, що процес самовизначення трактується як формування стійких та осмислених переконань, принципів, норм поведінки, ідеалів (К. Абульханова-Славська, Л. Орбан-Лембрик, С. Рубінштейн, В. Сафрін), інтенсивний афективний центр життєвої ситуації розвитку (О. Асмолов, Л. Божович, Л. Виготський).

у західній психології самовизначення здебільшого розглядається в контексті психотерапії як результат ідентифікації, пов'язаний із формуванням психосоціальної ідентичності (А. Ватерман, Е. Ериксон, Дж. Мід, Дж. Марсія), прагненням до самоствердження через подолання комплексу неповноцінності (А. Адлер), пошуком сенсу життя, самоактуалізацією (А. Маслоу, К. Роджерс, 
В. Франкл), адаптацією, відбором та створенням власної стратегії життя (А. Бандура), фрормуванням соціального характеру під впливом соціокультурних фракторів (А. Адорно, Е. Фромм).

Сьогодні зростає увага науковців до об'єктивних соціальних та соціальнопсихологічних чинників, які детермінують політичний вибір і політичну ідентифікацію як окремого індивіда, так і соціальних груп (В. Духневич, О. Ліщинська, Е. Ериксон, Л. Найдьонова, Т. Ньюкомб, В. Казміренко, Дж. Тернер).

В Україні цю проблематику, зокрема характер і властивості різних видів соціальних ідентифікацій та ідентичностей розробляли В. Павленко, М. Шульга, О. Злобіна, В. Тихонович, С. Макеєв, С. Оксамитна, О. Швачко, О. Симончук. Разом з тим бракує комплексної, концептуальної моделі структури політичної самоідентичності, що узагальнює попередні напрацювання в цьому напрямі, а також психологічного механізму політичної самоідентифрікації особистості.

Дослідниця В. Кутирьова вважає, що однією з найгостріших соціальних проблем українського суспільства $€$ соціально-психологічна неготовність більшості громадян бути активними учасниками трансформаційних процесів. Авторка вважає, що така неготовність визначається нездатністю людей до адекватного позиціонування у новому політичному континуумі та усвідомлення своїх політичних інтересів. А процес ідентифікації особистості з певною політичною ідеологією є одним з найважливіших показників її політичного самовизначення [13]. У період нестабільності трапляються випадки, коли особистість не ідентифікується із жодними політичними спільнотами. Обвальна криза українського суспільства призвела до особистісного психологічного дискомфорту - втрати соціальних ідентичностей, зокрема й політичних [14].

Дослідження Л. А. Тіхонової, яка провела пілотажне опитування на тему «Соціокультурна ідентичність студентської молоді в умовах інформаційного суспільства (на прикладі студентів вузів Слобожанщини)» також співвідносяться із тенденціями у політичному самовизначенні молоді Кременчука. Так, 42,1\% опитуваних студентів вважають себе такими, від яких нічого не залежить у сучасному українському суспільстві. Тільки 15,5\% відчувають себе «громадянином, позиція та вибір якого впливають на життя у нашій країні і майже така ж кількість - є «сторонніми спостерігачами» (14,6\%). Було з'ясовано, що поняття батьківщини для більшості респондентів $є$ скоріше географічним, ніж культурним або політичним. 76,5\% опитуваних вважають, що батьківщина, - це місце де народився і виріс. Тільки п'ята частина вважає, що їх тут цінують і поважають [15].

Відповідно, отримуючи статус громадянина, особа знаходиться під тиском певних прав та обов'язків, які скеровують її подальшу діяльність та вимагають відповідної політичної поведінки. Політична поведінка у свою чергу є одним із індикаторів політичної культури особи. Вона виражається як у зацікавленості та активній участі у політичному житті, так і в абсолютно пасивному стані, абсентеїзмі чи політичній невизначеності. Питання про мотивацію політичної участі або неучасті є дуже складним. I тут потрібно враховувати ще й психологічні аспекти.

Політична соціалізація передбачає достатньо високу автономію особистості в процесі вибору політичних позицій, їх довільну заміну, а також можливість керуватися в цьому процесі внутрішніми, часом несвідомими перевагами й переконаннями [16]. У політичній поведінці індивідів обов'язково $є$ певний елемент ірраціональності, впливу почуттів, симпатій та антипатій у процесі взаємодії.

Зараз коли в суспільстві одночасно співіснують антагоністичні суспільно-політичні цінності, представлені авторитарними і ліберально-демократичними позиціями, молодим людям важко самостійно визначитись у власних уподобаннях та інтересах. Ускладнюється цей процес такими віковими особливостями молоді, як домінування емоційного сприйняття подій, відсутність необхідного життєвого досвіду та ссрормованих світоглядних принципів [17]. На думку соціолога Є. Головахи особливої уваги заслуговує тенденція зміни базисного типу особистості, яка свідчить, що на нинішньому етапі свого розвитку українське суспільство за людськими ресурсами більш готове до демократичних перетворень, ніж у перші роки незалежності. Побільшало так званих «інтерналів» - людей, які відповідальність за своє життя покладають на самих себе [18].

Щодо особливостей мислення та поведінки українців, то можна виділити наступні. По-перше, індивідуалізм. В української ментальності індивідуалізм трансформується в таку поведінку, як соціальний егоїзм, тобто відмежованість від суспільних проблем, якщо вони безпосередньо не стосуються конкретної особистості. I як результат відсутність єдності в суспільстві і в політичному, і в економічному, і в регіональному, і в культурному аспекті. По-друге, перевага ірраціонального над 
раціональним, що сприяє суб'єктивізму суджень та оцінок. По-третє, це ригідність, якість, яка находить своє відображення у консерватизмі людей, що є слідством низької динаміки перетворень. Ригідність провокує соціальну пасивність. Ми більш схильні прямувати за подіями, ніж управляти ними.

\section{V Висновки}

Таким чином, уявлення людини про власну сутність, бажаний стиль життя та майбутнє пов'язане з її політико-ідеологічними уподобаннями.

Соціологічне дослідження показало, що юнацтво в цілому характеризуються певною невизначеністю політичних уподобань, що мабуть можна пояснити не тільки молодим віком опитуваних і їх спрямованістю виключно на свої егоїстичні інтереси, а й станом політичного життя сучасного українського суспільства, нестабільність якого відбивається на свідомості молодих громадян. Характерним $є$ також показник значної частки молоді, яка $є$ ідеологічно дезорієнтованою. Однією 3 важливих причин такого становища $є$ недостатній рівень уявлень молодих людей про існування різноманітних ідеологічних доктрин, про їх зміст, історію та завдання. 3 іншого боку не може не тішити той фракт, що серед студентської молоді юнацького віку не знаходять підтримки радикальні погляди як «лівого», та і «правого» спрямування. При цьому за останні роки посилилася орієнтованість української молоді на цінності індивідуалізму, досягнень, самостійності та конкурентоспроможності. Поряд 3 ними молоді люди розділяє основні демократичні орієнтири, а саме права і свободу громадян, проте при цьому не виявляють належного рівня інтересу до політичного життя суспільства. Подальша побудова ефективної моделі політичної соціалізації молоді доцільно проводити з опорою на конструктивну співпрацю держави, 3МІ та інститутів громадянського суспільства. Адже однією з особливостей молоді $є$ іï відкритість і здатність до громадянського діалогу, який $є$ найбільш якісним і швидким засобом досягненням компромісу на шляху побудови демократичної держави.

Молода людина, з огляду на внутрішні і зовнішні причини, має потребу переглянути своє ставлення до соціальних ролей, визначитися стосовно різних сфер життя - сімейної, професійної, статево-рольової, громадської, а також політичної. Складність такого вибору полягає не лише в слабкій структурованості, розмитості політико-ідеологічних орієнтацій і настановлень молоді, а й у недостатній актуалізації соціально-психологічних рис, що могли б допомогти самовизначитися.

Однією з особливостей молоді є їі відкритість і здатність до громадянського діалогу, який, на наш погляд, $€$ найбільш якісним і швидким засобом досягненням компромісу на шляху побудови демократичної держави.

Перспективними напрямами подальших досліджень проблеми політичного самовизначення $є$ з'ясування рефлексивних механізмів, які дадуть змогу якнайтісніше підійти до розуміння закономірностей активності українського молодіжного електорату, аналізу складної проблеми політичного абсентеїзму і його соціально-психологічних механізмів, що сприятимуть підвищенню виборчої активності населення, гендерні особливості громадянських орієнтацій молоді.

\section{Бібліографрічні посилання}

[1] Вишневский Ю. Р., Зырянова О. Б. Культура безопасности в системе культуры жизни / Вестн. Тюмен. гос. ун-та. Социально-экономические и правовые исследования. 2017. Т. 3. № 1. С. 32-41.

[2] Безруков А. В. Индивидуализация и локализация гражданского самоопределения современной российской молодежи в пространстве неудовлетворенности / Известия Уральского федерального университета. Сер. 3. Общественные науки. 2018. Т. 13. № 4 (182). С. 122-132.

[3] Агаларова К. Політико-ідеологічна ідентифікація як наукове поняття та соціальний феномен. Вісник ХНУ імені В. Н. Каразіна. Серія «Соціологічні дослідження сучасного суспільства: методологія, теорія, методи», (1122), 2015. С. 2932.

[4] Абрамова Г.С. Возрастная психология: учебн. пособие для студентов вузов. М.: Академический проект, 2000. С. 506525.

[5] Савчук О. В.. Динаміка ціннісних орієнтацій української молоді / Актуальні проблеми соціології, психології, педагогіки. 2012. Вип. 16. С. 60-67. URL: http://nbuv.gov.ua/UJRN/apspp_2012_16_10. (дата звернення 01.03.2019).

[6] Шамовская Т. В., Горбунова Г. П. Гражданская идентичность в структуре социальной идентичности современной молодежи / Проф. образование в России и за рубежом. 2016. № 4. С. 49-53. 
[7] Архипова Є. О. Патріотизм у розумінні сучасної молоді: аналіз результатів дослідження та динаміка основних показників. Державне управління: удосконалення та розвиток. 2018. № 7. URL: http://www.dy.nayka.com.ua/?op=1\&z=1269 (дата звернення: 08.04.2019).

[8] Тхоржевський Д. О. Національна самосвідомість як загальнолюдська цінність / Проблеми освіти. Науково-методичний збірник. К. : Наук.-метод. центр вищої освіти, 2000. Вип. 20. С. 3-4.

[9] Талько O. Мотивація електоральної поведінки студентської молоді Рівненщини. URL: https://naub.oa.edu.ua/2012/talko-o-motyvatsiya-elektoralnoji-povedinky-studentskoji-molodi-rivnenschyny/ I звернення: 08.04.2019).

[10] Ясінська А. Вплив мотивації як психологічного чинника політичної поведінки на електоральний вибір особи / Вісник Львівського університету. Серія філос.-політолог. студії. 2015. Вип. 6. С. 209-216.

[11] Гедікова Н. П. Обгрунтування сутності поняття «громадянська активність» у сучасному науковому дискурсі / Сучасне суспільство. 2016. Вип. 2. С. 53-64. URL:: http://nbuv.gov.ua/UJRN/cuc_2016_2_8. (дата звернення 21.03.2019).

[12] Гражданские позиции молодежи и студенчества в современной Украине (на примере Харьковского региона) : монография / [авт. кол.: В. И. Астахова, Е. В. Астахова и др. Харьков : Изд-во НУА, 2014. 176 с.

[13] У Укаїнське студентство у пошуках ідентичності: монографрія / за ред. В. Л. Арбєніної, Л. Г. Сокурянської. Харків: ХНУ імені В.Н.Каразіна, 2012. 520 c.

[14] Резнік О. Політична самоідентифікація особистості за умов становлення громадянського суспільства / О. Резнік. URL: http://isoc.com.ua/files/Reznik2003.pdf. (дата звернення: 09.04.2019).

[15] Тіхонова Л. А. Політична ідентичність сучасного українського суспільства / Вісник Харківського національного університету імені В. Н. Каразіна. Серія «Теорія культури і філософія науки». 2014. №1092. Вип.50. URL: https://periodicals. karazin.ua/thcphs/article/view/2211/1955 (дата звернення 15.03.2019).

[16] Загородній Ю ІІ., Кирилов В. С., Савченко С. В. Політична соціалізація студентської молоді в Україні: досвід, тенденції, проблеми. К.: Генеза, 2004. 144 с.

[17] Каретна О. О. Політична активність молоді як чинник становлення незалежності / Актуальні проблеми політики : зб. наук. пр. / редкол. С. В. Ківалов. Одеса : Фенікс, 2013. Вип. 48. С. 208-217.

[18] Бортніков В., Троценко В.Деякі проблеми політичної участі громадян в умовах демократичного транзиту / Політичний менеджмент. 2009. №1(34). С. 3-15.

\section{References}

[1] Vishnevskij, Yu., R., Zyryanova, O. B. (2017). Kultura bezopasnosti v sisteme kultury zhizni. Vestn. Tyumen. gos. un-ta. Socialno-ekonomicheskie i pravovye issledovaniya. 3, 1, 32-41. [in Russian]

[2] Bezrukov, A. V. (2018). Individualizaciya i lokalizaciya grazhdanskogo samoopredeleniya sovremennoj rossijskoj molodezhi v prostranstve neudovletvorennosti / Izvestiya Uralskogo federalnogo universiteta. Ser. 3. Obshestvennye nauki, 13, 4 (182), 122-132. [in Russian]

[3] Agalarova, K. (2015). Politiko-ideologichna identifikaciya yak naukove ponyattya ta socialnij fenomen. Visnik HNU imeni V. N. Karazina. Seriya «Sociologichni doslidzhennya suchasnogo suspilstva: metodologiya, teoriya, metodi», (1122), 29-32. [in Ukrainian]

[4] Abramova, G .S. (2000). Vozrastnaya psihologiya: uchebn. posobie dlya studentov vuzov. Moskva, 506-525. [in Russian]

[5] Savchuk, O. V. (2012). Dinamika cinnisnih oriyentacij ukrayinskoyi molodi. Aktualni problemi sociologiyi, psihologiyi, pedagogiki., 16, 60-67. URL: http://nbuv.gov.ua/UJRN/apspp_2012_16_10 (accessed 01.03.2019). [in Ukrainian]

[6] Shamovskaya, T. V., Gorbunova, G. P. (2016). Grazhdanskaya identichnost v strukture sotsialnoy identichnosti sovremennoy molodezhi. Prof. obrazovanie v Rossii i za rubezhom, 4, 49-53. [in Russian]

[7] Arhipova, Ye. O. (2018). Patriotizm u rozuminni suchasnoyi molodi: analiz rezultativ doslidzhennya ta dinamika osnovnih pokaznikiv. Derzhavne upravlinnya: udoskonalennya ta rozvitok, 7. URL: http://www.dy.nayka.com.ua/?op=1\&z=1269 (accessed 08.04.2019). [in Ukrainian]

[8] Thorzhevskij, D. O. (2000). Nacionalna samosvidomist yak zagalnolyudska cinnist. Problemi osviti. Naukovo-metodichnij zbirnik. Nauk.-metod. centr vishoyi osviti, 20, 3-4. [in Ukrainian]

[9] Talko, O. (2012). Motivaciya elektoralnoyi povedinki studentskoyi molodi Rivnenshini. URL: https://naub.oa.edu.ua/2012/talko-o-motyvatsiya-elektoralnoji-povedinky-studentskoji-molodi-rivnenschyny/ ～(accessed 08.04.2019). [in Ukrainian]

[10] Yasinska, A. (2015). Vpliv motivaciyi yak psihologichnogo chinnika politichnoyi povedinki na elektoralnij vibir osobi. Visnik Lvivskogo universitetu. Seriya filos.-politolog. Studiyi, 6, 209-216. [in Ukrainian]

[11] Gedikova, N. P. (2016). Obgruntuvannya sutnosti ponyattya "gromadyanska aktivnist» u suchasnomu naukovomu diskursi. Suchasne suspilstvo, 2, 53-64. URL: http://nbuv.gov.ua/UJRN/cuc_2016_2_8 (accessed 21.03.2019). [in Ukrainian]

[12] Grazhdanskie pozicii molodezhi i studenchestva v sovremennoj Ukraine (na primere Harkovskogo regiona) (2014): monografiya. avt. kol.: V. I. Astahova, E. V. Astahova i dr. Harkov, 176. [in Ukrainian]

[13] Ukrayinske studentstvo u poshukah identichnosti: monografiya. za red. V. L. Arbyeninoyi, L. G. Sokuryanskoyi. (2012). Harkiv, 520. [in Ukrainian]

[14] Reznik, O. (2003). Politichna samoidentifikaciya osobistosti za umov stanovlennya gromadyanskogo suspilstva URL: http://isoc.com.ua/files/Reznik2003.pdf (accessed 09.04.2019). [in Ukrainian]

[15] Tihonova, L. A. (2014). Politichna identichnist suchasnogo ukrayinskogo suspilstva. Visnik Harkivskogo nacionalnogo universitetu. «Teoriya kulturi i filosofiya nauki», 1092, 50. URL: https://periodicals.karazin.ua/thcphs/article/view/2211/1955 
(accessed 15.03.2019). [in Ukrainian]

[16] Zagorodnij, Yu .I., Kirilov, V. S., Savchenko, S. V. (2004). Politichna socializaciya studentskoyi molodi v Ukrayini: dosvid, tendenciyi, problemi, 144. [in Ukrainian]

[17] Karetna, O. O. (2013). Politichna aktivnist molodi yak chinnik stanovlennya nezalezhnosti. Aktualni problemi politiki : zb. nauk. pr. Odesa, 48, 208-217. [in Ukrainian]

[18] Bortnikov, V., Trocenko, V (2009). Deyaki problemi politichnoyi uchasti gromadyan v umovah demokratichnogo tranzitu. Politichnij menedzhment, 1(34), 3-15. [in Ukrainian]

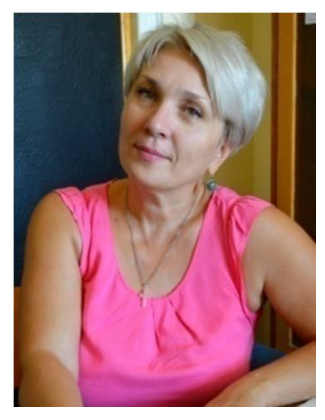

Лебединська Ганна Олександрівна.

Канд. політ. наук, доцент, доцент кафедри психології, педагогіки та філософії, Кременчуцький національний університет імені Михайла Остроградського, вул. Першотравнева, 20, м. Кременчук Полтавської обл., Україна, 39600. Тел. +38(096) 385-90-37. E-mail: lebedinskagunna@gmail.com

\section{Lebedynska Hanna Oleksandrivna.}

Cand.Sc. (Political), Associate Professor of Pedagogy and Philosophy Department, Kremenchuk Mykhailo Ostrohradskyi National University, vul. Pershotravneva, 20, Kremenchuk, Poltava Region, Ukraine, 39600. Phone: +38(096) 385-90-37. E-mail: lebedinskagunna@gmail.com

ORCID: 0000-0001-9320-6240

\section{Citation (APA):}

Lebedynska, A. (2019). Political self-determination of Ukrainian youth. Engineering and Educational Technologies, 7 (2), 170-180. doi: https://doi.org/10.30929/2307-9770.2019.07.02.17

\section{Цитування (ДСТУ 8302:2015):}

Лебединська Г. О. Політичне самовизначення українського юнацтва / Інженерні та освітні технології. 2019. Т. 7. № 2. С. 170180. doi: https://doi.org/10.30929/2307-9770.2019.07.02.17

Обсяг статmі: сторінок-11; умовних друк. аркушів- 1,593. 